\title{
Spiritual Leadership And Workplace Spirituality: The Role Of Organizational Commitment
}

\author{
Jufrizen', Maya Sari ${ }^{2}$, Muhammad Irfan Nasution ${ }^{3}$, Akrim $^{4}$, dan Muhammad Fahmi ${ }^{5}$ \\ \{jufrizen@umsu.ac.id ${ }^{1}$ \} \\ Faculty of Economics and Business, University Muhammadiyah of Sumatera Utara \\ Jalan Kapten Muchtar Basri No. 3 Medan, Indonesia
}

\begin{abstract}
This study aims to examine the spiritual leadership influence and workplace spirituality on the organizational commitment of lecturers of Islamic Private University in the city of Medan. The approach used in this study is associative approach; the location of this research is in University Muhammadiyah of Sumatera Utara, University of Muslim Nusantara. The population was all private university lecturers still owned by Islamic Organization, amounting to 425 permanent lecturers who have a functional position. Determination of the number was used by the formula Slovin and gained as much as 219 lecturers. Data collection techniques were interviews and questionnaires. Models and data analysis techniques were used by multiple linear regression analysis. The results showed that the Spiritual Leadership had positive and significant effect on organizational commitment of faculty and Workplace Spirituality had positive and significant impact on organizational commitment lecturer in Islamic Private University in the city of Medan.
\end{abstract}

Keywords: Organizational Commitment, Workplace Spirituality, Spiritual Leadership.

\section{Introduction}

In the face of increasingly prioritizing the development of the knowledge base, higher education has a very strategic role in the process of acculturation and the empowerment of the Indonesian people for the sake of human civilization. Similarly, the quality of education at the college will not be achieved if it is not supported by the human resources and one of the human resources that determine the success of an institution of higher learning is a lecturer.

Lecturers as professionals who deal directly with students are expected in his duties as an educator is able to execute policies with specific objectives and has a strong commitment to the university where she works. Organizational commitment basically emphasizes the relationship of faculty and work unit that can lead to posture as a sense of attachment to the philosophy or work unit, where lecturers will uphold wholeheartedly and promised to carry out tasks that must be carried out in strict accordance with the principles established by a group of persons or entities bound in a container of cooperation to achieve certain goals.

One's commitment to the institution lecturers is often a very important issue. However, although it is already very common, but not rare institutions and lecturers still do not understand the meaning of commitment seriously. Yet understanding these commitments is essential to create an atmosphere conducive working conditions so that the organization can run efficiently and effectively. A professor who has committed 
will have the identification of the organization, engaged in earnest and there is loyalty and positive affection towards the organization.

In modern society, stress and anxiety have become the norm of work. Lecturers often suffer from interpersonal alienation and fatigue in the workplace (Fry, 2003). Spirituality is a situation or experience that can provide direction or meaning for the individual or giving a feeling of understanding, the spirit, the integrity of the self or the feeling of being connected. Spirituality is also a process in the life of individuals, in the form of meaning and purpose, and all have an impact on other people and the environment, including the organization (Pargament \& Mahoney in King, 2007)

At present, it has developed the concept of spiritual leadership is a universal concept of adaptive leadership to answer the challenges of the times in the era of the 21 st century that the terms with the changes, which are not answered by the leadership of today's organizations (Sureskiarti, 2015). The concept of spiritual leadership is believed to be the solution to the leadership crisis at the moment, due to the increasing deterioration of human values as a result of their ethical malaise and ethical crisis (Tobroni, 2015).

In connection with the lecturer, it was realized that the satisfaction and fullness of life which continue to be pursued by the organization / institution by meeting the psychological needs and spiritual, can create an atmosphere conducive for employees to do their best. Organization / institution that want to succeed must use its best endeavours to meet the spiritual needs (Bagir in (Azlimin and Hakim, 2015). Spirituality will benefit the organization and leadership, because spirituality in the workplace able to demonstrate the contribution through improved performance, turnover is low, productivity is high and various other organizational effectiveness criteria (Giacolone and Jurkiewicz, 2003).

\section{Literature Review}

\subsection{Organizational Commitment}

Organizational commitment can be defined two different ways, first proposed by (Mowday, Steers and Porter, 1982); and the second way proposed by (Becker, 1960). According to (Porter et al., 1974) was the strong commitment and involvement of the introduction of a person in a particular organization. On the other hand, (Becker, 1960) describes the commitment as a tendency to be bound in a consistent line of activity because it considers the cost of implementing another (stop working).

(Griffin, 2005) states the organization's commitment is an attitude that reflects the extent to which an individual to know and adhere to the organization. O'Reilly (in (Coetzee, 2005) adds a commitment is a psychological attachment felt by a person of the organization, and it will reflect the degree to which individuals internalize or adopts characteristics or perspectives of the organization. (Meyer and Allen, 1997) formulated a definition of the commitment in the organization as a psychological construct which is characteristic of members of the organization relationship with the organization and has implications for an individual's decision to continue its membership in the organization.

(Steers, 1977) states the organization's commitment to explain the relative strength of an individual's identification with involvement in an organization. The commitment to bring something beyond mere loyalty to an organization. In addition, it includes an active relationship with the organizations in which individuals are willing to give 
something of themselves to help the organization's success and prosperity. Welsch and La Van in (Davis and Newstrom, 2002) states the company's commitment is an important behavioral dimensions and can be used to assess employee engagement in companies. This is supported by (Davis and Newstrom, 2002) which states that the organization's commitment to the company is the level of employee willingness to identify itself in the company, and for his desire to continue active participation in the company.

The determining factors are the organizational commitment variables (age, tenure in the organization and distribution of such positive or negative, affect or control the position of the internal and external) and the organization (design work and leadership styles supervisor) (Luthans, 2006). (Steers, 1977) developed a model of the antecedents of organizational commitment that includes: (1) the personal characteristics, (2) the characteristics associated with the job or position, and (3) work experience. According to Allen and Meyer (Luthans, 2006) reflects the organization's commitment of three components: 1) Affective Commitment, occurs when employees want to be part of the organization for their emotional bond, 2) continuance commitment, arising from the values in the employees who survive to become members of the organization because of the awareness that commitment to the organization is something that should be done.

\subsection{Workplace Spiritual}

Fox (1994) in (Ashmos and Duchon, 2000) states that in order to understand the term Workplace sprituality must begin with the recognition that each person has a personal life (inner) and outer life (outer), and that the development of personal life can lead to the outdoor life more more meaningful and productive. Workplace sprituality means looking at the workplace as a place inhabited by people who have a mind (intellect) and the spirit, and believe that the development of the spirit is as important as developing the mind (Ashmos and Duchon, 2000). Workplace spirituality involves the effort to find one's ultimate purpose in life, to develop a strong connection to coworkers and other people associated with work, and to have consistency (or alignment) between one's core beliefs and the values of their organization (Mitroff and Denton in (Milliman, Czaplewski and Ferguson, 2003). Workplace sprituality is one kind of psychological climate in the workplace. Workplace spirituality is one kind of psychological climate in which people (workers) saw itself has an internal life treated with meaningful work and placed in the context of a community (Duchon and Plowman, 2005). Workplace sprituality includes meaningful work, sense of community, and alignment of values (Milliman, Czaplewski and Ferguson, 2003). In the Handbook of Workplace Spirituality and Organizational Performance (Giacolone and Jurkiewicz, 2003), a number of writers give definitions are slightly different, but many of them take the components of the definition developed by (Ashmos and Duchon, 2000): the inner life, meaningful work, and the community. The definition of spirituality in the workplace, according to (Ashmos and Duchon, 2000) contains three dimensions: (a) the inner life (b) meaningful work, and (c) community. Furthermore, Workplace spirituality can provide benefits for leadership and organization, as Workplace spirituality is able to contribute significantly through improved performance, lower turnover, higher productivity and the various other organizational effectiveness criteria (Giacolone and Jurkiewicz, 2003). 


\subsection{Spiritual Leadership}

The concept of spiritual leadership emerged as a new paradigm in the transformation and development of the organization adaptive to the challenges of the times in the era of the 21st century. Spiritual leadership is deemed able to enhance the leadership of previous models by basing the vision, mission and leadership behavior on the values of divinity (Tobroni, 2015). Further (Tobroni, 2015) argued that the spiritual leadership is a leadership that can inspire, arouse, influence and mobilize by example, care, affection and implementation of the values and divinity in others the purpose, the process of cultural and leadership behaviors. In other words, spiritual leadership is a leadership that makes spiritual values as core beliefs, core values and philosophies in leadership behaviors. Spiritual leadership is a set of values, attitudes and behaviours required to motivate themselves or others intrinsically, so that every member of the organization has the feeling of survival of a spiritual nature through membership and skills (Fry, 2003). According to (Fry, 2003) spiritual leadership is the formation of values, attitude, behaviour needed to motivate yourself and others in the intrinsic motivation to achieve a sense of spiritual survival through calling and membership.

The characteristics of spiritual leadership (spiritual leadership) are: (1) Vision is the most important part that attracts attention to see what is desired by the organization in the short term and long term. This vision is a picture of the future is hidden (implicit) or clear (explicit) because why someone struggling to reach the future "(Kotter, 1996). (2) Altruistic Love, the mission is the reason why an organization exists and is a basic determination in making the vision.

\section{Methods}

The approach used in this study is associative approach. This study was conducted in University Muhammadiyah of Sumatera Utara and University of Muslim Nusantara. The population was all private university lecturers still owned by Islamic Organization, amounting to 425 permanent lecturers who have a functional position. Determination of the number of samples will give accurate results according to a formula Slovin (Umar, 2003) and is obtained as many as 219 people. The sampling technique in this study is conducted a random sample proportion or proportional random sampling. The sample unit is used lottery technique without refund. Data collection techniques are interviews and questionnaires. Data analysis models and techniques use descriptive analysis approach and data analysis is used is multiple linear regression analysis.

\section{Result And Discussion}

\subsection{Correlation Analysis}

Correlation analysis is used to measure the linear association between the two variables. The correlation value of 1 indicated that the variables were perfectly positively correlated whereas the value of -1 indicated that the variables were perfectly negatively correlated and the correlation value of 0 indicated that there is no correlation between the variables (Waluyo, 2018). Examining the correlation value, it was found that all the variables have strong correlation. Spiritual Leadership and workplace spirituality have strong correlation value 0.340 , and 0.348 respectively. Additionally, it was found that the correlation was significant and positive. 


\subsection{Hypothesis}

Regression analysis was used to test the hypothesis. For this purpose, the p-value and $\beta$-value was considered. For a significant $\mathrm{p}$-value relationship should be less than $0.05(\mathrm{p} \leq 0,05)$. Table 2 shows the results of regression analysis. Table 2 shows that the spiritual leadership has a significant relationship with organizational commitment having $p$-value of 0.004 . Beta value 0.253 shows a positive relationship. Hence, $\mathrm{H} 1$ is accepted. Similarly, the relationship of workplace spirituality with organizational commitment IS ALSO significant with p-value of 0.002 , beta value 0.264 .

Table 1. Regression Results.

\begin{tabular}{|c|c|c|c|c|}
\hline $\begin{array}{l}\text { Hypothe } \\
\text { sis }\end{array}$ & $\begin{array}{c}\text { Variable } \\
\text { Model }\end{array}$ & $\begin{array}{c}\text { t - } \\
\text { Val } \\
\text { ue }\end{array}$ & $\mathbf{P}$ & Results \\
\hline H1 & $\begin{array}{l}\mathrm{S} \rightarrow \mathrm{O} \\
\mathrm{L}\end{array}$ & $\begin{array}{c}2,97 \\
1\end{array}$ & $\begin{array}{c}0,00 \\
4\end{array}$ & $\begin{array}{l}\text { Support } \\
\text { ed }\end{array}$ \\
\hline $\mathrm{H} 2$ & $\begin{array}{l}\mathrm{W} \rightarrow \mathrm{O} \\
\mathrm{S}\end{array}$ & $\begin{array}{c}3,10 \\
2\end{array}$ & $\begin{array}{c}0,00 \\
2\end{array}$ & $\begin{array}{l}\text { Support } \\
\text { ed }\end{array}$ \\
\hline
\end{tabular}

Note:

$\mathrm{SL}=$ Spiritual Leadership $\mathrm{WS}=$ Workplace Spirituality, $\mathrm{OC}=$ Organizational Commitment

\subsection{Influence of Spiritual Leadership on Organizational Commitment}

Results of testing the first hypothesis (H1) indicated that the spiritual leadership had positive and significant effect on organizational commitment lecturer in Islamic Private University in the city of Medan. This means that by applying a good spiritual leadership to affect the increased organizational commitment Private lecturer at the University of Islam in the city of Medan. The results are consistent with the results of research conducted by (Scott and Tweed, 2016), (Udin, Handayani and Bakhri, 2017), (Usman and Danish, 2010) and (Arshad and Abbasi, 2014), (Azlimin and Hakim, 2015) concluded that spiritual leadership influence on organizational commitment.

\subsection{Influence of Workplace Spirituality on Organizational Commitment}

Results of testing the second hypothesis (H2) suggested that workplace spirituality had positive and significant effect on organizational commitment lecturer in Islamic Private University in the city of Medan. This shows that the high level of spirituality in the workplace can increase organizational commitment lecturers. The results are consistent with (Rego and Cunha, 2008), (Khanifar, Jandaghi and Shojaie, 2010) showed that there is positive influence between workplace spirituality on organizational commitment. Furthermore, Workplace spirituality morale, commitment and employee productivity due to reduced stress and fatigue (Ajala, 2013); (Miller et al., 2012) and (Chand and Koul, 2012).

\section{Conclusion}

Based on the research results, it can be concluded that: Spiritual Leadership had positive and significant impact on organizational commitment lecturers. Workplace 
Spirituality had positive and significant impact on organizational commitment lecturer in Islamic Private University in the city of Medan.

The results of the analysis, discussion and conclusions are some suggestions that can be used as a material consideration in determining future policy primarily related to organizational commitment of lecturers among others related to the spiritual leadership that should build love each other so it will increase the organization's commitment lecturers. Variable workplace spirituality is to build belonging in the community by encouraging the growth indicator of personality that will make employees feel change and contribute to the organization and will have an impact on improving the organizational commitment of lecturers. This study is only on the Private Islamic University in the city of Medan then you should forward the broader scope covering all private universities in the city of Medan.

\section{References}

[1] Ajala, E. . (2013) 'he Impact of Workplace Spirituality and Employees' Wellbeing at the Industrial Sector: The Nigerian Experience', The African Symposium: The African Educational Research Network, 13(2), pp. 1-13.

[2] Arshad, A. and Abbasi, A. S. (2014) 'Spiritual Leadership And Psychological Ownership: Mediating Role Of Spiritual Wellbeing', Science International, 26(3), pp. 1265-1269.

[3] Ashmos, D. P. and Duchon, D. (2000) 'Workplace spirituality: A conceptualization and measure', Journal of Management Inquiry, 9(2), pp. 134145.

[4] Azlimin, A. and Hakim, A. (2015) 'Model Peningkatan Komitmen Sumber Daya Manusia Berbasis Spiritual Leadership Dan Spiritual Survival Serta Workplace Spirituality Dengan Moderating Individual Spirituality', Unissula, 2, pp. 344 356. Available at: https://media.neliti.com/media/publications/169794-IDmodel-peningkatan-komitmen-sumber-daya-m.pdf.

[5] Becker, H. S. (1960) 'Notes On The Concept Of Commitment', The American Journal of Sociology, 66(1), pp. 32-40.

[6] Chand, P. and Koul, H. (2012) 'Workplace Spirituality, Organizational Emotional Ownership and Job Satisfaction as Moderators in Coping with Job Stress', in International Conference on Humanities, Economics and Geography (ICHEG'2012). Bangkok, pp. 225-229.

[7] Coetzee, M. (2005) 'Employee Commitment', in. University of Pretoria. Available https://repository.up.ac.za/bitstream/handle/2263/23942/05chapter5.pdf?sequenc $\mathrm{e}=6$.

[8] Davis, K. and Newstrom, J. W. (2002) Organization Behavior : human behavior at work. Boston, Mass: McGraw - Hill.

[9] Duchon, D. and Plowman, D. D. (2005) 'Nurturing the spirit at work: Impact on work unit performance', The Leadership Quarterly, 16(5), pp. 807-833.

[10] Fry, L. W. (2003) 'Toward a theory of spiritual leadership', The Leadership Quarterly, 14, pp. 693-727.

[11] Giacolone, R. A. and Jurkiewicz, C. L. (2003) 'Handbook of Workplace Spirituality and Organizational Performance', in. New York: M.E Sharpe. Inc.

[12] Griffin, R. (2005) Management. Boston: Houghton Mifflin Company. 
[13] Khanifar, H., Jandaghi, G. and Shojaie, S. (2010) 'Organizational Consideration between Spirituality and Professional Commitment', European Journal of Social Sciences, 12(4), pp. 558-571.

[14] King, S. M. (2007) 'Religion, Spirituality, and the Workplace: Challenges for Public Administration', Public Administration Review, 67(1), pp. 103-114.

[15] Luthans, F. (2006) Organizational Behavior: An Evidence-Based Approach. New York: McGraw - Hill, Irwin.

[16] Meyer, J. P. and Allen, N. J. (1997) dvanced topics in organization behavior series. Commitment in the workplace: Theory, research, and application. Thousand Oaks, CA: Sage Publications, Inc.

[17] Miller, L. et al. (2012) 'Religiosity and major depression in adults at high risk: a ten-year prospective study', American Journal of Psychology, 169(1), pp. 89-94.

[18] Milliman, J., Czaplewski, A. J. and Ferguson, J. (2003) 'Workplace spirituality and employee work attitudes: An exploratory empirical assessment', ournal of Organizational Change Management, 16(4), pp. 426-447. doi: https://doi.org/10.1108/09534810310484172.

[19] Mowday, R. T., Steers, R. M. and Porter, L. W. (1982) Employee-Organization Linkages: The Psychology of Commitment, Absenteeism and Turnover. New York: Academic Press, Inc.

[20] Porter, L. W. et al. (1974) 'Organizational commitment, job satisfaction, and turnover among psychiatric technicians', Journal of Applied Psychology, 59(5), pp. 603-609.

[21] Rego, A. and Cunha, M. P. e (2008) 'Workplace spirituality and organizational commitment: an empirical study', Journal of Organizational Change Management, 21(1), pp. 53-75.

[22] Scott, P. H. and Tweed, S. (2016) 'Implications of Spiritual Leadership on Organizations', Journal of Education \& Social Policy, 3(6), pp. 66-70.

[23] Steers, R. M. (1977) 'Antecedents and Outcomes of Organizational Commitment', Administrative Science Quarterly, 22(1), pp. 46-56.

[24] Sureskiarti, E. (2015) Pengaruh Spiritual Leadership terhadap Kinerja Perawat dalam Melaksanakan Asuhan Keperawatan di RSUD Dr. H. Soewondo Kendal. Program Studi Magister Keperawatan Fakultas Kedokteran Universitas Diponegoro.

[25] Tobroni (2015) 'Spiritual leadership: a solution of the leadership crisis in islamic education in indonesia', British journal of education, 3(11), pp. 40-53.

[26] Udin, U., Handayani, S. and Bakhri, S. (2017) 'Udin', International Journal of Pharmacy \& Technology, 9(1), pp. 28106-28121.

[27] Usman, A. and Danish, R. Q. (2010) 'Leadership Spirituality in Banking Professionals and Its Impact on Organizational Commitment', International Journal of Business and Management2, 5(3), pp. 185-193.

[28] Waluyo (2018) 'The Effect of Tax Service Quality in Promoting Online Tax System in Indonesia', . Journal of Applied Economic Sciences, XIII(3 (57)), pp. 649-654. 